\title{
Bybelse lig val helder op sterwensgebeure
}

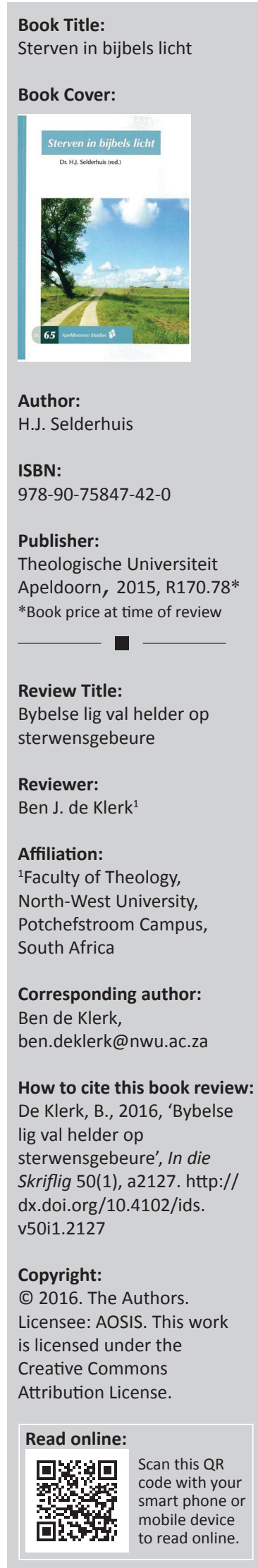

Sterven in bijbelse licht was die tema van 'n reeks voordragte aan die Theologische Universiteit Apeldoorn gefokus op die breë publiek. Hierdie voordragte word in 'n bundel aangebied om besinning oor die aspekte wat met die sterwe te make het, te stimuleer. J. Dekker beskryf die OuTestamentiese perspektiewe op sterwe en dui aan dat sterwe in die Ou Testament nie as 'n probleem gesien word nie, veral as die Here die persoon geseën het met 'n lang lewe en nageslag. Belangrik is ' $n$ goeie begrafnis verkieslik in jou eie land en op jou eie grond. Hoewel enkele Psalms versigtig oor die grens van die dood woorde uiter, spekuleer die gelowiges in die Ou Testament nie oor lewe na die dood nie.

Vanuit 2 Korintiërs 4:16-5:10 handel T.E. van Spanje oor sterwe van 'n Christen volgens die Nuwe Testament. Paulus beskou sy sterwe as die voltooiing van 'n proses wat reeds tydens sy aardse lewe begin het. Die volgende hoofpunte kry voorts die skrywer se aandag: sterwe en persoonlike oordeel, sterwe as verhuising uit die buiteland na die tuisland, die tussentoestand waarin alle gestorwe Christene in die teenwoordigheid van die Here is, en sterwe en eskatologiese vewagting. In die Nuwe Testament is die verlange na die wederkoms so groot dat dit die heerlikheid van die deurgang van die gelowige by sy en/of haar sterwe oortref.

G.C. de Hertog benader die dood as vraag aan die lewe vanuit die etiek. Hy ontwikkel die onderwerp om tot die belangrike afleiding te kom dat die gesprek oor dood en lewe by Paulus en Johannes beteken om weg van jouself na Hom te wys wat die opstanding en die lewe is. Ook om tegelyk self te laat sien wat liefde inhou wat sterker is as die dood, wat die angs daarvoor oorwin en mense vrymaak om hulle vir ander te gee.

In 'n boeiende voordrag skryf H.J. Selderhuis oor Calvyn se belewing van sterwe en dood onder die opskrif wat Calvyn aanhaal: 'Wij zijn altijd onderweg naar de dood'. Hy skryf aangrypend oor Calvyn se ervaring van die dood van sy pasgebore seuntjie en van sy vrou Idelette se sterwe. Calvyn erken die angs vir die sterwe, maar dieper as die angs om te sterf is die angs vir wat onmiddellik na die dood gebeur: die angs om voor God te verskyn as 'n sondige mens. Calvyn het geweldige ontsag vir God. Tegelyk is daar 'n verlange om by God te wees, en die sekerheid dat God die liggaam sal opwek. Veral aan die einde van sy eie lewe skryf Calvyn oor die verlange na die dood. Hy skryf aan Melanchthon dat hy graag fees wil vier in die hemel.

C.T. de Groot skryf en preek rondom die graf en gee 'n omvattende oorsig oor die geskiedenis van begrafnispreke. Die rol van die prediker en riglyne vir die begrafnispreek word getrek. Dat daar ook voortdurend aandag aan die sterwensuur in die prediking gegee moet word, is die pleitdooi van M.J. Kater. Hy dui aan dat die dood omarm word deur die lewe en skryf waarom daar preke gelewer moet word oor die dood. Hy neem die woestynreis om 'n beeld te gee van ons lewensreis as uittog, deurtog en intog. In die lewe moet daar 'n uittog uit die dood van die sonde op grond van Christus se verdienste kom. Omdat ons met Christus sterwe is die navolging van Christus as sy dissipel 'n lewe deur die dood heen tot die lewe, elke dag van die aardse bestaan. Die uittog en deurtog lei tot die intog, die opstanding in die onverganklike lewe.

Hierdie kompakte boek oor die sterwe in Bybelse lig reken voluit met die tragiek van die dood as gevolg van die sonde, maar bied wonderlike perspektiewe op die lewe. Dit gaan wel oor die ewige lewe by God en die lewe na die wederkoms van Christus, maar ook oor die lewe hier en nou, die lewe verlos van die dood. Dit is aangrypend om Calvyn se persoonlike pyn en troos van die dood van sy geliefdes te hoor. Dit en ander aspekte in die boek plaas die vraagstuk van sterwe, sterwensoomblik en verwerking van die sterwe in die konkrete lewe van elke dag.

Omdat die voordragte aangebied is vir die breë publiek sal die boek vir ernstige ondersoekers van die Bybel toeganklik wees. Veral almal wat met die pastoraat en berading van sterwensbegeiding werk, sal hieruit goeie perspektiewe kan kry. Die hoek van benadering is in ooreenstemming met die gereformeerde belydenis. Die inhoud kan met vrymoedigheid aanbeveel word. 